\title{
Effects of Defoliation on Net Photosynthesis and Regrowth of Western Wheatgrass
}

\author{
E.L. PAINTER AND J.K. DETLING
}

\section{Abstract}

Net photosynthesis $\left(\mathrm{P}_{\mathrm{N}}\right)$ and regrowth of 60-day old Agropyron smithii Rydb. plants were examined over a 10-day period following defoliation to simulate grazing. Plants grown hydroponically in full strength Hoagland's solution were moderately defoliated (1/2 tillers clipped at $5 \mathrm{~cm}$ ), heavily defoliated (3/4 tillers clipped at 5 $\mathrm{cm})$, or left as unclipped controls. Thirty minutes after clipping, $P_{N}$ rates of the youngest fully expanded leaf of a remaining undamaged tiller had declined by $6 \%-7 \%$ in both groups of defoliated plants. Rates of $P_{N}$ were subsequently monitored on the same leaves at 2-day intervals. By Day 2, $P_{N}$ (per unit of leaf area) of both defoliated groups had increased to rates $5-10 \%$ higher than those preceding treatment, while $P_{N}$ of control plants had decreased about 6\%. From Day 2 through Day 10, $P_{N}$ rates of control plants averaged $90 \%$ of their preclipping $P_{N}$ rates, while $P_{N}$ rates of moderately and heavily defoliated plants averaged $106 \%$ and $114 \%$ of their preclipping rates, respectively. Defoliation had no significant effect on tiller production over this 10-day period. While total new biomass production of controls was almost twice that of either of the defoliated groups, the proportion of the new growth allocated to shoots, crowns and roots did not differ among the three groups.

In most terrestrial ecosystems, herbivores remove less than $10 \%$ of the annual aboveground net primary production (Chew 1974), but they may consume $50 \%$ or more of the annual aboveground production of grasslands (Chew 1974, McNaughton 1976). To achieve better understanding of grassland ecosystem function, it is essential to understand how these herbivores cause departures from the linear transfers of energy depicted in most models (Chew 1974). For example, in addition to reducing leaf biomass, grazing may potentially alter energy flow in the system by changing photosynthetic or respiratory rates, growth rates, and carbon allocation patterns.

Following partial defoliation, photosynthetic rates in remaining undamaged leaves frequently increase or decline less rapidly with age than do those in equivalent leaves on nondefoliated plants (Gifford and Marshall 1973, Hodgkinson et al. 1972, Hodgkinson 1974, Detling et al. 1979b, 1980). By contrast, Ryle and Powell (1975) reported slightly reduced photosynthetic rates in remaining leaves of partially defoliated uniculm barley (Hordeum Kindred Culm 97) plants. Net photosynthesis was also reduced in remaining

\footnotetext{
Authors are graduate research assistant and associated director, Natural Resource Ecology Laboratory, Colorado State University, Fort Collins 80523.

The research was supported by National Science Foundation Grant DEB 7681821 Authors thank Donna Winn and Vicky Chamberlain for their technical assistance, and Marilyn Campion for performing the statistical analyses.

Manuscript received October 30, 1979.
}

tissue of individually da maged leaves (Hall and Ferree 1975, 1976; Detling et al. 1979a). Carbon allocation and growth patterns also change following defoliation. Ryle and Powell (1975) found that the proportion of photosynthetically fixed ${ }^{14} \mathrm{C}$ translocated from leaves to roots was markedly reduced, while the proportion used in regrowth of new leaf tissue increased, following defoliation of uniculm barley. Similarly, leaf blade growth accounted for over half of the total new growth of defoliated blue grama (Bouteloua gracilis) plants, but only one-third of the total growth of control plants, over the initial 10 days after clipping (Detling et al. 1979b).

Relatively few studies have been conducted to evaluate the photosynthetic responses of North American prairie grasses to defoliation (Detling et al. 1979a, b, 1980). The purpose of this study was to examine the effects of simulated grazing on rates of net photosynthesis $\left(\mathrm{P}_{\mathrm{N}}\right)$ and regrowth of western wheatgrass (Agropyron smithii Rydb.), an important component of the North American shortgrass and mixed-grass prairies. It is a $C_{3}$ species (Williams and Markley 1973) and is a preferred food of several species of grasshoppers (Hewitt 1978), of ungulates such as bison and domestic cattle (Peden et al. 1974, Peden 1976), and of small mammals such as the black-tailed prairie dog (Summers and Linder 1978).

\section{Methods and Procedures}

Western wheatgrass seedlings selected for uniformity were cultured hydroponically in full strength Hoagland's solution in a growth chamber with 14 -hr photoperiods and $20 / 15^{\circ} \mathrm{C}$ day/night temperatures. Quantum irradiance (PAR) at midcanopy height was $450 \mu \mathrm{E} \cdot \mathrm{m}^{-2} \cdot \mathrm{s}^{-1}$. Experimental plants were maintained under these conditions for the duration of the experiments. Estimates of $\mathrm{P}_{\mathrm{N}}$ were made by measuring $\mathrm{CO}_{2}$ exchange of a single leaf blade with Beckman 315 infrared gas analyzer, utilizing an open system and methods described by Williams and Kemp (1978). The cuvette was cooled by circulating water from a controlled-temperature water bath. Air in the cuvette was mixed by a magnetic stirring bar to maintain low boundary layer resistance. Air temperature in the cuvette was maintained at $20^{\circ} \mathrm{C} \pm 0.5^{\circ}$, measured with a shaded YSI thermister. Quantum irradiance within the cuvette was 1200 $\mu \mathrm{E} \cdot \mathrm{m}^{-2} \cdot \mathrm{s}^{-1}$.

Experimental plants were 60 days old and each had four tillers with from one to four fully expanded leaves. The tiller used for $P_{N}$ measurements was not clipped and it had two fully expaned leaves and one emerging leaf blade. All $\mathrm{CO}_{2}$ exchange measurements were made on the youngest fully expanded leaf. Plants were clipped $5 \mathrm{~cm}$ above the crown, at two intensities. Six plants were moderately defoliated by clipping one-half of all tillers over $5 \mathrm{~cm}$ 
tall. Six others were heavily defoliated by removing three-quarters of any tillers over $5 \mathrm{~cm}$ tall. Thus, $P_{\mathrm{N}}$ rates were determined on similarly aged leaves of comparably developed undamaged tillers remaining after defoliation. Likewise, $\mathrm{CO}_{2}$ exchange was measured on similar leaves of seven untreated plants which served as controls. On the day of treatment (Day 0), $\mathrm{P}_{\mathrm{N}}$ was measured immediately before and 30 minutes after clipping. Rates of $P_{N}$ were subsequently determined on the same leaves of defoliated and control plant every other day over the next 10 days. All data were normalized by expressing $\mathrm{P}_{\mathrm{N}}$ as a percentage of the preclipping $\mathrm{P}_{\mathrm{N}}$ rate of that leaf.

Regrowth of western wheatgrass was analyzed in another experiment utilizing 108 plants. Plants were treated as before, and dry weights determined for shoots, crowns, and roots of 9 plants of each treatment on Days 0, 2, 6, and 10. Total tiller number and number of tillers with expanded leaves were also recorded on those days.

\section{Results and Discussion}

Immediately prior to treatment on Day $0, P_{\mathrm{N}}$ rates $( \pm 1 \mathrm{SE})$ were $24.1 \pm 1.9,24.8 \pm 2.2$, and $22.9 \pm 0.8 \mathrm{mg} \mathrm{CO} \cdot \mathrm{dm}^{-2} \cdot \mathrm{h}^{-1}$ for the controls, moderately defoliated, and heavily defoliated plants, respectively. These rates are similar to those found by Detling et al. (1979a), for soil-grown western wheatgrass plants transplanted from the field. Over the ten days of the experiment (Fig. 1), $\mathrm{P}_{\mathrm{N}}$ of the controls decreased $10 \%$ to $21.6 \mathrm{mg} \mathrm{CO} \cdot \mathrm{dm}^{-2} \cdot \mathrm{h}^{-1}$. This decline also corresponds closely to results of Detling et al. (1979a) and is typical in aging leaves (Jewiss and Woledge 1967).

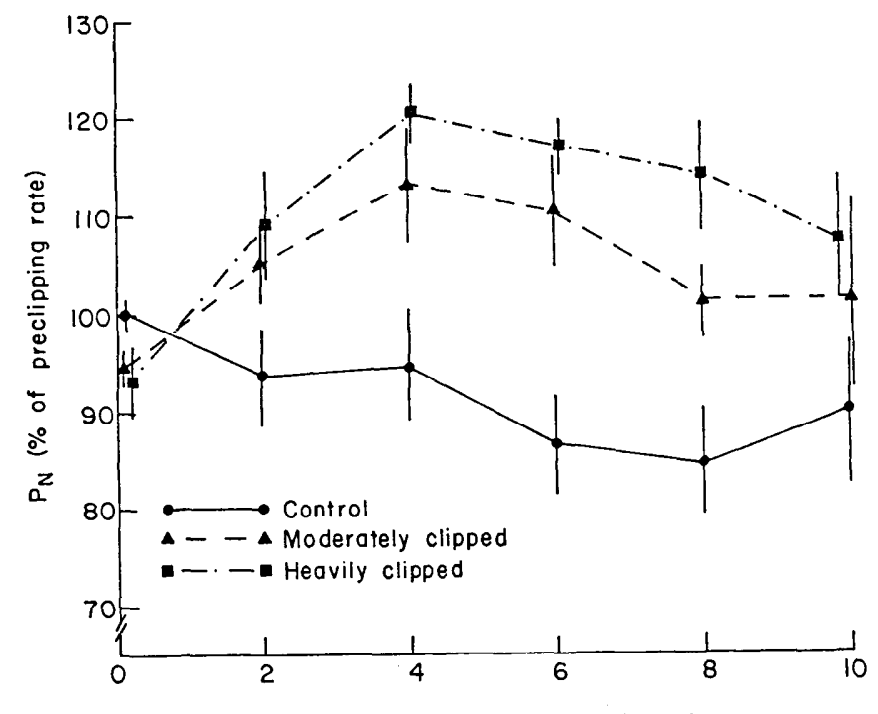

TIME FROM CLIPPING (days)

Fig. 1. Rates of net photosynthesis (expressed as \% of preclipping rate) in youngest fully expanded leaf on an undamaged tiller. Each point represents the mean of 6-7 plants. Vertical bars represent $\pm 1 S E$.

The mean $\mathrm{P}_{\mathrm{N}}$ rates of the two groups of clipped plants dropped 6-7\% by 30 minutes after treatment, but this decline did not occur in control plants (Fig. 1). Results of Duncan's new multiple range test indicated that this decrease was significant at $p=0.10$ and $p$ $=0.05$ for the moderately and heavily defoliated plants, respectively. A similar response was found by Ryle and Powell (1975). Van Sambeek and Pickard (1976) reported that injury to a single leaf could affect gas exchange of an entire shoot, and net $\mathrm{CO}_{2}$ uptake decreased in as little as $20 \mathrm{~s}$. They hypothesized that this was related to metabolic changes caused by the release of unidentified substances from damaged cells into the transpiration stream, and suggested that some of these changes might be involved in later responses of plants to damage by pathogens, herbivores, and physical factors.

By Day $2, \mathrm{P}_{\mathrm{N}}$ rates in both clipped groups had increased to rates higher than those preceding treatment (Fig. 1). Analysis of var-

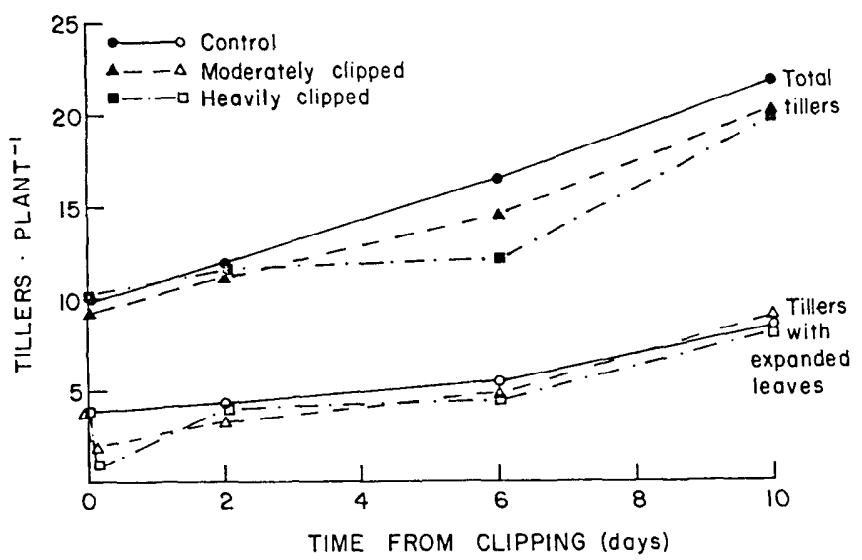

Fig.2. Total tiller production and production of tillers with at least one expanded leaf. Each point represents the mean of 9 plants. Standard errors (omitted for clarity) averaged $9 \%$ of the mean values shown and did not exceed $13 \%$.

iance of data from Days 2-10 indicated that there was not a significant time by treatment interaction $(p=0.16)$, but that there was a significant treatment effect $(p=0.01)$. Results of the Student Newman Keuls test indicated that $P_{\mathrm{N}}$ rates of both the moderately $(p=0.05)$ and heavily $(p=0.01)$ defoliated plants were significantly greater than those of the controls. However, $P_{N}$ rates between the two treatment groups did not differ significantly $(p>$ 0.10 ).

This enhancement of photosynthesis in undamaged leaves remaining following partial defoliation is consistent with the results of several others (Wareing et al. 1968, Gifford and Marshall 1973, Hodgkinson 1974, Detling et al. 1979b, 1980). The physiological basis for this response was not investigated in this study. Results of defoliation studies with alfalfa (Medicago sativa) (Hodgkinson et al. 1972, Hodgkinson 1974) and ryegrass (Lolium spp.) (Gifford and Marshall 1973, Deinum 1976) suggest increases in $\mathbf{P}_{\mathbf{N}}$ rates result largely from decreases in mesophyll resistance to $\mathrm{CO}_{2}$ diffusion. In addition, Wareing et al. (1968) proposed that increases in RuDP carboxylase (in $\mathrm{C}_{3}$ plants) or PEP carboxylase (in $\mathrm{C}_{4}$ plants) activity may occur following defoliation because of increased enzyme synthesis. This might result from decreased competition by remaining leaves for mineral nutrients, metabolitcs or cytokinin supplied by the roots. This explanation is consistent with increased RuDP carboxylase activity observed in soybean (Glycine $\max$ ) source leaves following shading of remaining leaves and pods (Thorne and Koller 1974).

The regrowth experiment parallelled the photosynthesis experiment. By the end of 10 days, there was little variation in tiller number among the clipped and unclipped plants (Fig. 2). Controls had a mean of 8.6 tillers with expanded leaves, moderately defoliated plants had 9.1, and heavily defoliated plants had 8.3. There was also little difference in total tiller number. On Day 10, control plants had 21.9 tillers, moderately defoliated plants had 20.2 and heavily defoliated plants had 19.9. Apparently few apical meristems were removed by clipping, since less than $20 \%$ of the clipped tillers failed to regrow. These results differ from those of a number of other investigators. Defoliation without removal of shoot apices usually depresses tillering (Youngner 1972, Youngner et al. 1976, Ackerson and Chilcote 1978), while tiller production is usually enhanced when defoliation removes shoot apices (Youngner 1972). Detling et al. (1980) found that tillering of hydroponically-grown blue grama decreased with increasing levels of defoliation for the first 4-6 weeks following treatment, but that these differences had disappeared by 10 weeks after defoliation.

Total new growth of the clipped plants was significantly $(p=$ 0.01 ) lower than that of control plants over the 10-day period (Fig. 3 ), but the proportional distribution of this new growth did not differ perceptibly among the three groups of plants (Table 1). This differs markedly from other studies (Ryle and Powell 1975; Detling 
Table 1. Growth and dry matter accumulation of various plant parts of $\boldsymbol{A}$. smithii over 10 days following defoliation.

\begin{tabular}{|c|c|c|c|c|c|c|c|}
\hline \multirow[b]{2}{*}{ Treatment } & \multirow{2}{*}{$\begin{array}{c}\text { Total } \\
\text { new } \\
\text { growth } \\
\text { mg }\end{array}$} & \multicolumn{2}{|c|}{$\begin{array}{c}\text { New shoot } \\
\text { growth }\end{array}$} & \multicolumn{2}{|c|}{$\begin{array}{c}\text { New crown } \\
\text { growth }\end{array}$} & \multicolumn{2}{|c|}{$\begin{array}{c}\text { New root } \\
\text { growth }\end{array}$} \\
\hline & & $\mathrm{mg}$ & $\begin{array}{l}\% \text { of } \\
\text { total }\end{array}$ & $\mathrm{mg}$ & $\begin{array}{l}\% \text { of } \\
\text { total }\end{array}$ & $\mathrm{mg}$ & $\begin{array}{l}\% \text { of } \\
\text { total }\end{array}$ \\
\hline Control & 898 & 707 & 79 & 52 & 6 & 140 & 15 \\
\hline Moderately defoliated & 488 & 386 & 79 & 24 & 5 & 79 & 16 \\
\hline Heavily defoliated & 474 & 364 & 77 & 26 & 5 & 85 & 18 \\
\hline
\end{tabular}

et al. 1979b, 1980), in which there was proportionately less dry weight gain in the roots of the defoliated plants than in those of the controls. The slight decrease in dry weight of the roots of both clipped groups on Day 2 (Fig. 3) is consistent with results of laboratory experiments of Ryle and Powell (1975) and Detling et al. (1979b). This suggests that insufficient photosynthate was translocated to the roots to meet respiration demands, or that root-to-shoot translocation exceeded downward translocation during this timc. By six days after clipping, root growth had apparently resumed (Fig 3). Collectively, these results suggest that athough $\mathbf{P}_{\mathrm{N}}$ rates increased significantly in undamaged leaves remaining following partial defoliation, these increases were insufficient to compensate completely for reduced photosynthate production resulting from decreased leaf area.

Earlier, Detling et al. (1979b) concluded that the response of blue grama plants to grazing was a rapid restoration of their carbon gain capacity caused by increased $P_{N}$ rates as well as an increase in the proportion of photosynthates allocated to synthesis of new leaf blades. Our results indicate that while $P_{N}$ of remaining leaves of western wheatgrass increased following defoliation (Fig. 1), photosynthate allocation patterns were not substantially altered (Table 1). This might partially explain why western wheatgrass is less grazing tolerant than blue grama (Ellison 1960), since carbon allocation patterns may be as important as photosynthetic rates in determining primary productivity (Mooney 1972, Detling et al. 1979c).

As mentioned earlier, $\mathrm{P}_{\mathrm{N}}$ rates of these hydroponically grown western wheatgrass plants are nearly identical to those reported for soil-grown western wheatgrass plants raised under the same temperature and light conditions (Detling et al. 1979a). In addition, Kemp and Williams (1980) found that, in contrast to blue grama, the photosynthetic response of western wheatgrass to a wide range of temperatures was the same regardless of whether plants were grown in hydroponic culture or soil. Nevertheless, caution should be exercised when attempting to extrapolate from these laboratory results to field conditions, since plants grown in growth chambers, greenhouse, and field environments sometimes exhibit different growth characteristics from one another (Bazzaz 1973). For example, while Ludlow and $\mathrm{Ng}$ (1976) reported that photosynthetic light response curves and maximum $P_{\mathrm{N}}$ rates were similar for Panicum maximum plants grown outdoors and in controlled environment chambers, Patterson et al. (1977) found that cotton plants grown in growth chambers became light saturated at lower light intensities and had lower light-saturated $P_{N}$ rates than did plants raised in the field.

In the field, primary production is not only affected directly by changes in physiological processes resulting from defoliation, but it is also influenced by environmental changes caused by grazing. In semiarid rangelands, for instance, decreases in photosynthetic production brought about by reduced leaf area after grazing might be partially compensated for by prolonged periods of favorable soil water conditions as a result of reduced transpirational water losses (Detling et al. 1979b, McNaughton 1979). A variety of additional potential direct and indirect effects of grazers on primary production were recently reviewed by McNaughton (1979). Further studies of these various processes are necessary to more thoroughly understand the mechanisms involved in forage

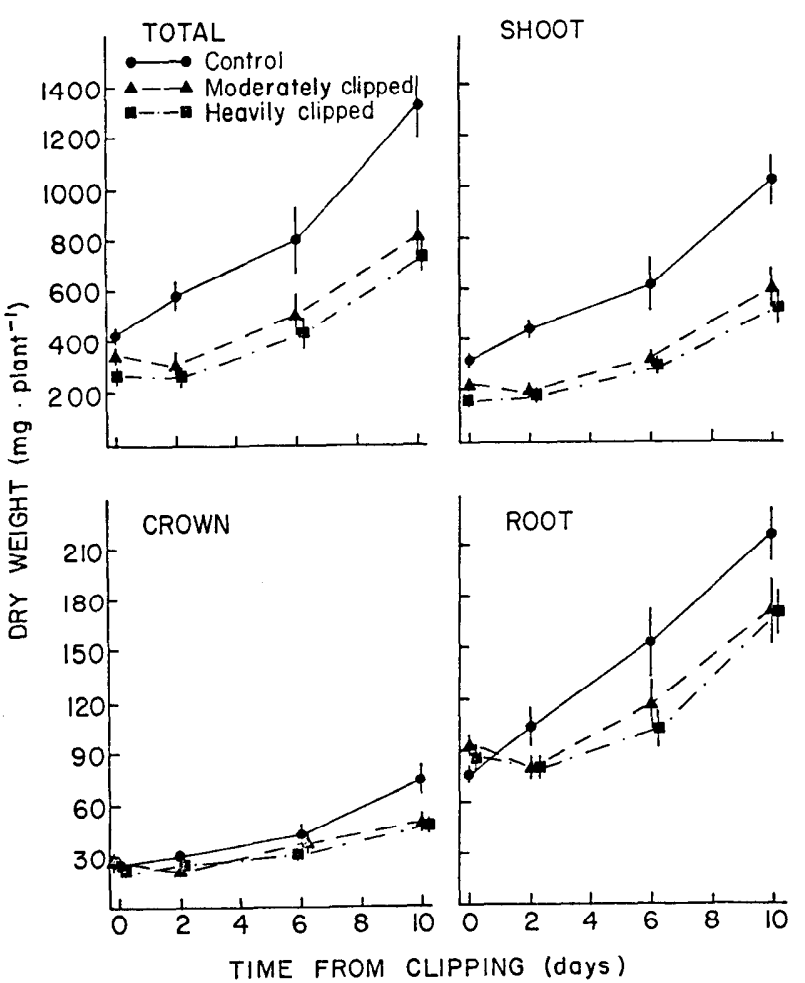

Fig. 3. Growth ( $m g$ ) of A. smithii over 10 days following defoliation. Each point represents the mean of 9 plants. Vertical bars represent $\pm 1 S E$.

production in grassland grazing systems.

\section{Literature Cited}

Ackerson, R.C., and D.0. Chilcote. 1978. Effects of defoliation and TIBA (Triiodobenzoic acid) on tillering, dry matter production, and carbohydrate reserves of two cultivars of Kentucky bluegrass. Crop Sci. 18:705-708.

Chew, R.M. 1974. Consumers as regulators of ecosystems: An alternative to energetics. Ohio J. Sci. 74:359-370.

Deinum, B. 1976. Photosynthesis and sink size: An explanation for the low productivity of grass swards in autumn. Neth. J. Agr. Sci. 24:238-246.

Detling, J.K., M.I. Dyer, and D.T. Winn. 1979a. Effect of simulated grasshopper grazing on $\mathrm{CO}_{2}$ exchange rates of western wheatgrass leaves. J. Econ. Entomol. 72:403-406.

Detling, J.K., M.I. Dyer, and D. Winn. 1979b. Net photosynthesis, root respiration, and regrowth of Bouteloua gracilis following simulated grazing. Oecologia 41:127-134.

Detling, J.K., W.J. Parton, and H.W. Hunt. 1979c. A simulation model of Bouteloua gracilis biomass dynamics on the North American shortgrass prairie. Oecologia 38:167-191.

Detling, J.K., M.I. Dyer, C. Procter-Gregg, and D.T. Winn. 1980. Plantherbivore interactions: Examinations of potential effects of bison saliva on regrowth of Bouteloua gracilis (H.B.K.) Lag. Oecologia 45:26-31.

Ellison, L. 1960. Influence of grazing on plant succession of rangelands. Bot. Rev. 26:1-78.

Gifford, R.M., and C. Marshall. 1973. Photosynthesis and assimilate distribution of Lolium multiflorum Lam. following differential tiller defoliation. Aust. J. Biol. Sci. 26:517-526.

Hall, F.R., and D.C. Ferree. 1975. Influence of two-spotted spider mite populations on photosynthesis of apple leaves. J. Econ. Ent. 68:517-520.

Hall, F.R., and D.C. Ferree. 1976. Effects of insect injury simulation on photosynthesis of apple leaves. J. Econ. Ent. 60:245-248.

Hewitt, G.B. 1978. Reduction of western wheatgrass by feeding of two rangeland grasshoppers, Aulocara elliotti and Melanoplus infantilis. J. Range Manage. 29:376-380.

Hodgkinson, K.C. 1974. Influence of partial defoliation on photosynthesis, photorespiration, and transpiration by lucerne leaves of different ages. Aust. J. Plant Physiol. 1:561-578.

Hodgkinson, K.C., N.G. Smith, and G.E. Miles. 1972. The photosynthetic capacity of stubble leaves and their contribution to growth of the lucerne plant after high level cutting. Aust. J. Agr. Res. 23:225-238. 
Jewiss, O.R., and J. Woledge. 1967. The effect of age on the rate of apparent photosynthesis in leaves of tall fescue (Festuca arundinacia Schred.). Ann. Bot. 31:661-671.

Kemp, P.R., and G.J. Williams. 1980. A physiological basis for niche separation between Agropyron smithii $\left(\mathrm{C}_{3}\right)$ and Bouteloua gracilis $\left(\mathrm{C}_{4}\right)$. Ecology 61:846-858.

Ludlow, M.M., and T.T. Ng. 1976. Photosynthetic light response curves of leaves from controlled environment facilities, glasshouses or out doors. Photosynthetica 10:457-462.

McNaughton, S.J. 1979. Grazing as an optimization process. Grass ungulate relationships in the seienget: Amer. Natur. 113:691-703.

McNaughton, S.J. 1976. Serengeti migratory wildebeest: Facilitation of energy flow by grazing. Science 191:92-94.

Mooney, H.A. 1972. The carbon balance of plants. Ann. Rev. Ecol. Syst. 3:315-346.

Patterson, D.T., J.A. Bunce, R.S. Alberte, and E.B. Van Volkenburgh. 1977. Photosynthesis in relation to leaf characteristics of cotton from controlled and field environments. Plant Physiol. 59:384-387.

Peden, D.G. 1976. Botanical composition of bison diets on shortgrass plains. Amer. Mid. Natur. 96:225-229.

Peden, D.G., G.M. VanDyne, R.W. Rice, and R.M. Hansen. 1974. The trophic ecology of Bison bison L. on shortgrass plains. J. Appl. Ecol. 11:489-498.

Ryle, G.J.A., and C.E. Powell. 1975. Defoliation and regrowth in the graminaceous plant: The role of current assimilate. Ann. Bot. 39:297310.
Summers, C.A., and R.I. Lirder. 1978. Food habits of the black-tailed prairie dog in western South Dakota. J. Range Manage. 31:134-136.

Thorne, J.H., and H.R. Koller. 1974. Influence of assimilate demand on photosynthesis, diffusive resistances, translocation, and carbohydrate levels of soybean leaves. Plant Physiol. 54:201-207.

VanSambeek, J.W., and B.G. Pickard. 1976. Mediation of rapid electrical, metabolic, transpirational, and photosynthetic changes by factors released from wounds. 1II. Measurements of $\mathrm{CO}_{2}$ and $\mathrm{H}_{2} \mathrm{O}$ flux. Canadian J. Bot. 54:2662-2671.

Wareing, P.F., M.M. Khalifa, and K.M. Treharne. 1968. Rate-limiting processes in photosynthesis at saturating light intensities. Nature, Lond on. 220:453-457.

Williams, G.J., III, and P.R. Kemp. 1978. Simultaneous measurement of leaf and root gas exchange of shortgrass prairie species. Bot. Gaz. 139:150-157.

Williams, G.J., III, and J.L. Markley. 1973. The photosynthetic pathway type of North American shortgrass prairie species and some ecological implications. Photosynthetica 7:262-270.

Younger, V.B. 1972. Physiology of defoliation and regrowth. In: V.B. Youngner and C.M. McKell, (eds.) The Biology and Utilization of Grasses, p. 292-303. Academic Press, New York and London.

Younger, V.B., R. Nudge, and R. Ackerson. 1976. Growth of Kentucky bluegrass leaves and tillers with and without defoliation. Crop. Sci. $16: 110-113$.

\title{
Range Management Planning Position Department of Forestry and Range Management Washington State University
}

The range management planning position in the Department of Forestry and Range Management at Washington State University is to be filled at the Assistant Professor level. It is tenuretrack, 12-month appointment apportioned 75 percent teaching and 25 percent research. Occupancy of the position is scheduled for September 1, 1981.

The basic assignments associated with the position are:

1. To develop and implement a graduate and research program in rangeland and associated forest planning;

2. To teach a graduate course in rangeland and associated forest planning; and

3. To teach an undergraduate course in the economics and planning of range livestock grazing.

Applicants are required to have: Ph.D. degree in which land-use planning and economics are emphasized; training and experience with quantitative analysis of natural resource problems; and at least one degree in range management or a demonstrated professional interest in range management.

The salary associated with the position will be commensurated with the training and experience of the person to whom the position is offered.

The Department of Forestry and Range Management is a component of the College of Agriculture. The department has three basic curricula, namely, forestry, range management, and wildland recreation. Presently, it has 21 faculty members, 155 certified majors, and 33 graduate students. Graduate programs are offered only at the M.S. level. The forestry program is accredited by the Society of American Foresters. The department is presently seeking accreditation from the Society for Range Management of its range management program.

Applicants are to furnish a complete resume, academic transcripts, and at least three letters of reference. These documents are to be sent to:

\author{
Dr. Benjamin Zamora \\ Chairman, Range Management Planning Search Committee \\ Department of Forestry and Range Management \\ Washington State University \\ Pullman, Washington 99164
}

Closing date for the receipt of applications for the position is March 15, 1981 (or until a suitable candidate is found.)

Washington State University Is an Equal Opportunity-Affirmative Action Employer. In order to assist the university's effort is meeting its affirmative action goals, minority and women candidates are encouraged to identify themselves as such in their application. 